\title{
In vitro micropropagation of pointed gourd (Trichosanthes dioica Roxb.) from shoot tip and nodal segment
}

\author{
Amdadul Huq, Shahina Akter, Shahina Islam and Salim Khan \\ Plant Tissue Culture Section, Biological Research Division, Bangladesh Council of Scientific and Industrial \\ Research, Dhanmondi, Dhaka-1205, Bangladesh
}

\begin{abstract}
An efficient protocol was developed for plant regeneration, multiplication and rooting under in vitro condition in pointed gourd. Highest percent of shoot regeneration was $91.66 \%$, when nodal explants were cultured on MS+1.0 mg/1 BAP. The maximum number of shoots (4.8) per explant was observed in MS $+1.0 \mathrm{mg} / 1 \mathrm{BAP}+0.2 \mathrm{mg} / 1 \mathrm{NAA}$ from nodal segment. Among the two explants, nodal segment was found better for shoot regeneration and multiplication. The best response towards root induction was achieved on half MS medium supplemented with $0.4 \mathrm{mg} / 1 \mathrm{NAA}$. The regenerated healthy rooted plantlets were transferred to small plastic pot containing garden soil and compost in a ratio of 2:1. Immediately after transplantation the plantlets were covered with polythene bag to prevent desiccation. After acclimatization the plantlets were successfully transferred to the garden soil and the percentage of survivability in such condition was $90 \%$.
\end{abstract}

Key Words: In vitro multiplication, Shoot regeneration, Pointed gourd, Transplantation, Acclimatization.

\section{Introduction}

Pointed gourd (Trichosanthes dioica Roxb.) locally known as 'patal' is an important vegetable in Bangladesh. The Bengal and Assam region of India is the primary centre of its origin (Singh et al., 1992). It is grown almost in every districts of Bangladesh, especially in Rajshahi, Bogra, Pabna, Jessore and Kushtia (Rashid, 1993). It is a perennial crop and available in the market to the end of October when there is a scarcity of vegetables. The fruit is the edible part of the plant which is cooked in various ways either alone or in combination with other vegetables or meats. The pointed gourd is one of the most nutritive cucurbit vegetables that holds a coveted position in the vegetable market during summer and rainy season (Singh et al., 1992). Patal is a good source of carbohydrates, protein, vitamin A and C. Pointed gourd proteins showing peroxidase activity (Satar and Husain, 2009). It also contains a variety of trace elements considered beneficial for the human physiology, such as magnesium, potassium, copper, sulphur and chlorine (Singh, 1989). From the ayurvedic point of view, it is a tridoshic vegetable and is excellent for the balancing of all five fundamental elements. It is extremely ojas enhancing, easy to digest and assimilate into the physiology, does not create any ama and is nurturing for all seven layers of the skin. The fruits are easily digestible and diuretic in nature. It is febrifuge, laxative and antibilious (Vashista, 1974). Play important role in circulatory system, especially in lowering total cholesterol and blood sugar (Chandrasekar et al., 1988; Sharma et al., 1988). It is also known to have antiulcerous effects (Som et al., 1993). The aqueous extract of Trichosanthes dioica leaves has good hypoglycemic potential along with a high anti-diabetic profile. It has also high industrial value as different types of jam, jelly and pickles can be made from this vegetable. Fresh juice of unripe fruit is used as cooling and laxative. The fruit is also used in spermatorrhoea (Sharma, 2004).

Pointed gourd is multiplied through stem cuttings and root suckers usually by the farmers. But stem and root cuttings are labor intensive and also require bulk amount of vines and roots, which restrict their multiplication at commercial level and ultimately increase its cost. Propagation using seed is not feasible primarily due to poor germination (Kumar et al., 2007). Seed based populations have a tendency to give more male than female plants and in some cases the ratio goes up to $85: 15$ (Som et al., 1993). In such a case, in-vitro multiplication of elite clones will be an attractive approach in order to meet the requirement of quality propagules at large scale for commercial cultivation. The present study was, therefore, undertaken to develop a micro-propagation protocol for plant regeneration of pointed gourd through in-vitro culture of shoot tip and nodal segment. 


\section{Materials and Methods}

The experiment was conducted at Plant Tissue Culture Section, Bangladesh Council of Scientific and Industrial Research (BCSIR), Dhanmondi, Dhaka. Healthy and profusely growing vines of pointed gourd were collected from various places of Bangladesh such as Magura, Kushtia and Manikgang and used as sources of explants for this experiment. Shoot tips and stem nodes with a single axillary bud were used for this experiment. The explants were surface sterilized with soft detergent for three times followed by washing with a few drops of Tween 20 and thoroughly washed in running tap water for 20-25 minutes. Then the explants were transferred in autoclaved plastic pot and treated with $0.1 \%$ mercuric chloride $\left(\mathrm{HgCl}_{2}\right)$ for 5 minutes for surface sterilization. The sterilized explants were then rinsed 4-5 times with sterile distilled water inside the clean bench to remove all traces of $\mathrm{HgCl}_{2}$. The sterilized explants were excised in the laminar airflow cabinet aseptically using a fine sterile forceps and scalpel. The excised explants were then inoculated in MS (Murashige and Skoog, 1962) medium supplemented with alone or combination of $\operatorname{BAP}(0.5,1.0$, $1.5,2.0,2.5 \& 3.0 \mathrm{mg} / 1), \mathrm{Kn}(0.5,1.0,1.5,2.0,2.5,3.0 \mathrm{mg} / \mathrm{l})$, NAA $(0.1,0.2,0.3,0.4,0.5 \mathrm{mg} / \mathrm{l})$, IAA $(0.1,0.3,0.5,1.0$ $\mathrm{mg} / \mathrm{l})$ and $\operatorname{IBA}(0.1,0.3,0.5,1.0 \mathrm{mg} / \mathrm{l})$ for shoot regeneration and multiplication. The $\mathrm{pH}$ of the medium was adjusted to $5.7 \pm 0.1$ using $0.1 \mathrm{~N}$ sodium hydroxide $(\mathrm{NaOH})$ or $0.1 \mathrm{~N}$ HCI. In order to solidify the media, laboratory grade agar of $5.5 \mathrm{~g}(0.55 \%)$ was added to the solution. The culture tubes were plugged with aluminum foil and marked with glass marker pen to indicate specific hormonal supplement. The culture tubes were sterilized at $1.09 \mathrm{~kg} / \mathrm{cm}^{2}$ pressure at $121^{\circ} \mathrm{C}$ for 15 minutes in an autoclave. After autoclaving, the culture media were taken out and allowed to cool and solidify. The cultures were maintained in the temperature set on $26 \pm 1{ }^{\circ} \mathrm{C}$ with a light intensity of 2000-3000 lux from fluorescent tubular lamps. The maintained photoperiod was 16 hours light and 8 hours dark (16 L/8 D) and relative humidity of $60-70 \%$.

Successful shoot formations become evident when small green fresh leaves began to emerge. Subcultures carried out regularly at an interval of 4-5 weeks. The percentage of explant induced shoot, days to shoot initiation and number of shoots per explant have been recorded after four weeks of culture. In vitro shoots of pointed gourd were cultured in $1 / 2$ MS medium supplemented with different concentrations of NAA $(0.1,0.2,0.3,0.4,0.5$ and $1.0 \mathrm{mg} / 1)$, IAA $(0.1,0.3,0.5$, $1.0 \mathrm{mg} / \mathrm{l})$ and $\operatorname{IBA}(0.1,0.3,0.5,1.0 \mathrm{mg} / \mathrm{l})$ for root initiation. The well rooted plantlets were then kept in room temperature for 2-3 days and transferred to plastic pot containing garden soil and compost in ratio of 2:1 and moist them adequately for proper hardening.

\section{Results and Discussion}

The regeneration response from shoot tips and nodal segments of pointed gourd in different concentrations of BAP and $\mathrm{Kn}$ is presented in Table I. The regeneration of shoots

Table I: Effect of different concentrations of BAP and Kn on shoot induction and proliferation from nodal segment and shoot tip explants of pointed gourd

\begin{tabular}{|c|c|c|c|c|c|c|}
\hline \multirow{2}{*}{$\begin{array}{l}\text { Growth } \\
\text { regulators } \\
(\mathrm{mg} / \mathrm{l})\end{array}$} & \multicolumn{3}{|c|}{ Shoot tip } & \multicolumn{3}{|c|}{ Nodal segment } \\
\hline & $\begin{array}{c}\text { Shoot } \\
\text { induction }(\%)\end{array}$ & $\begin{array}{l}\text { Days to shoot } \\
\text { initiation }\end{array}$ & $\begin{array}{c}\text { Shoot number/ } \\
\text { explant }\end{array}$ & $\begin{array}{c}\text { Shoot } \\
\text { induction }(\%)\end{array}$ & $\begin{array}{c}\text { Days to } \\
\text { shoot initiation }\end{array}$ & $\begin{array}{c}\text { Shoot number/ } \\
\text { explant }\end{array}$ \\
\hline \multicolumn{7}{|l|}{ BAP } \\
\hline 0.5 & 13.33 & 10 & 1.50 & 8.33 & 10 & 2.30 \\
\hline 1.0 & 80.00 & 8 & 3.25 & 91.66 & 7 & 4.00 \\
\hline 1.5 & 73.33 & 7 & 3.00 & 83.33 & 7 & 3.50 \\
\hline 2.0 & 53.33 & 8 & 2.25 & 58.33 & 7 & 2.70 \\
\hline 2.5 & 20.00 & 9 & 2.00 & 8.33 & 8 & 2.25 \\
\hline 3.0 & 6.66 & 10 & 1.90 & - & - & - \\
\hline \multicolumn{7}{|l|}{ Kn } \\
\hline 0.5 & 8.33 & 10 & 1.75 & 11.11 & 10 & 1.80 \\
\hline 1.0 & 41.66 & 8 & 2.00 & 44.44 & 9 & 2.20 \\
\hline 1.5 & 58.33 & 8 & 2.25 & 66.66 & 9 & 2.30 \\
\hline 2.5 & 8.33 & 10 & 2.00 & 11.00 & 9 & 1.90 \\
\hline 3.0 & - & - & - & - & - & - \\
\hline
\end{tabular}


varied both with the type of explants and kind of supplements used. In MS + $1.0 \mathrm{mg} / 1 \mathrm{BAP}$ and MS $+1.5 \mathrm{mg} / 1 \mathrm{BAP}$, it took the shortest time ( 7 days) for shoot induction. Among different concentrations, MS $+1.0 \mathrm{mg} / 1 \mathrm{BAP}$ showed higher percentage of shoot induction $(91.66 \%)$ and maximum number of shoots per explant (4.00) from nodal segments. Shoot initiation and proliferation from shoot tip explant on MS medium supplemented with $1.0 \mathrm{mg} / 1 \mathrm{BAP}$ are shown in Fig. A. In case of $\mathrm{Kn}, \mathrm{MS}+1.5 \mathrm{mg} / 1 \mathrm{Kn}$ higher percentage of shoot induction (66.66\%) and maximum number of shoots per explant (2.30) from nodal segments were found and it was $58.33 \%$ and 2.25 respectively, for shoot tip explant. The ability of BAP to induce auxillary branching is well documented (George, 1993). In general, herbaceous plants are highly responsible to BAP treatments and most of the cultures produce robust well formed shoots suitable for further shoot proliferation (Debergh and Zimmerman, 1991).

The results on different concentrations and combinations of BAP with Kn, NAA, IAA, and IBA from shoot tip and nodal segments shown in Table II indicates that MS medium with $1.0 \mathrm{mg} / 1 \mathrm{BAP}+0.2 \mathrm{mg} / 1 \mathrm{NAA}$ regenerated higher percentage of shoot induction (88.88\%) and maximum number of shoots per explant (4.80) from nodal segment than any other combinations in both explants. The greater respons of nodal explants over shoot apices can be attributed to the absence of apical dominance and the presence of axillary buds in more advanced stage of development. It may be mentioned here that, the shoot apex displays apical dominance, which might result from auxin produced at the terminal bud. Due to apical dominance, the lateral bud formation is suppressed. In apple (Hutchiunson, 1981) and Thom less blackberry (Zimmerman and Broome, 1980) nodal segments proved to be good explants for micropropagation. The results reported here indicate that, nodal segment was more suitable for shoot regeneration and multiplication and also maximum shoot elongation. These results were in agreement with the findings of Debnath et al. (2000) and Uddin (2000) in pointed gourd. Zaman et al. (1992) demonstrated similar effects of BAP on shoot elongation in nodal segments culture of Verbena spp. (Hosoki and Katahira, 1994).

For acclimatization of micropropagated shoots, it is necessary to develop sufficient root. Different auxins NAA, IAA and IBA were used in different concentrations on half strength of MS basal medium for root induction (Table III). Among the three auxins NAA showed best response of root induction. The effectiveness of half-strength MS medium

Table II: Effect of different concentrations and combinations of BAP with Kn, NAA, IAA and IBA on shoot induction and proliferation from nodal segment and shoot tip explants of pointed gourd

\begin{tabular}{|c|c|c|c|c|c|c|}
\hline \multirow{2}{*}{$\begin{array}{l}\text { Growth } \\
\text { regulators } \\
(\mathrm{mg} / \mathrm{l})\end{array}$} & \multicolumn{3}{|c|}{ Shoot tip } & \multicolumn{3}{|c|}{ Nodal segment } \\
\hline & $\begin{array}{c}\text { Shoot } \\
\text { induction }(\%)\end{array}$ & $\begin{array}{l}\text { Days to shoot } \\
\text { initiation }\end{array}$ & $\begin{array}{c}\text { Shoot number/ } \\
\text { explant }\end{array}$ & $\begin{array}{c}\text { Shoot } \\
\text { induction }(\%)\end{array}$ & $\begin{array}{c}\text { Days to } \\
\text { shoot initiation }\end{array}$ & $\begin{array}{c}\text { Shoot number/ } \\
\text { explant }\end{array}$ \\
\hline \multicolumn{7}{|l|}{$\mathrm{BAP}+\mathrm{Kn}$} \\
\hline $1.0+0.5$ & 58.33 & 8 & 3.20 & 62.50 & 10 & 3.40 \\
\hline $1.0+1.0$ & 66.66 & 8 & 3.60 & 75.00 & 8 & 3.80 \\
\hline $1.0+1.5$ & 33.33 & 9 & 3.40 & 50.00 & 9 & 3.25 \\
\hline $1.0+2.0$ & 16.66 & 10 & 2.90 & 25.00 & 10 & 3.00 \\
\hline \multicolumn{7}{|l|}{$\mathrm{BAP}+\mathrm{NAA}$} \\
\hline $1.0+0.1$ & 58.33 & 8 & 3.25 & 77.77 & 8 & 4.10 \\
\hline $1.0+0.2$ & 75.00 & 8 & 4.25 & 88.88 & 7 & 4.80 \\
\hline $1.0+0.3$ & 50.00 & 8 & 3.80 & 55.55 & 8 & 4.20 \\
\hline $1.0+0.5$ & 33.33 & 9 & 3.20 & 44.44 & 9 & 3.80 \\
\hline \multicolumn{7}{|l|}{$\mathrm{BAP}+\mathrm{IAA}$} \\
\hline $1.0+0.1$ & 60.00 & 9 & 3.20 & 62.50 & 9 & 3.35 \\
\hline $1.0+0.5$ & 40.00 & 10 & 3.10 & 50.00 & 9 & 3.45 \\
\hline $1.0+1.0$ & 30.00 & 11 & 2.90 & 25.00 & 11 & 3.10 \\
\hline \multicolumn{7}{|l|}{$\mathrm{BAP}+\mathrm{IBA}$} \\
\hline $1.0+0.1$ & 60.00 & 9 & 3.25 & 70.00 & 9 & 3.45 \\
\hline $1.0+0.3$ & 50.00 & 10 & 3.10 & 60.00 & 9 & 3.20 \\
\hline $1.0+1.0$ & 30.00 & 11 & 2.70 & 30.00 & 11 & 2.80 \\
\hline
\end{tabular}



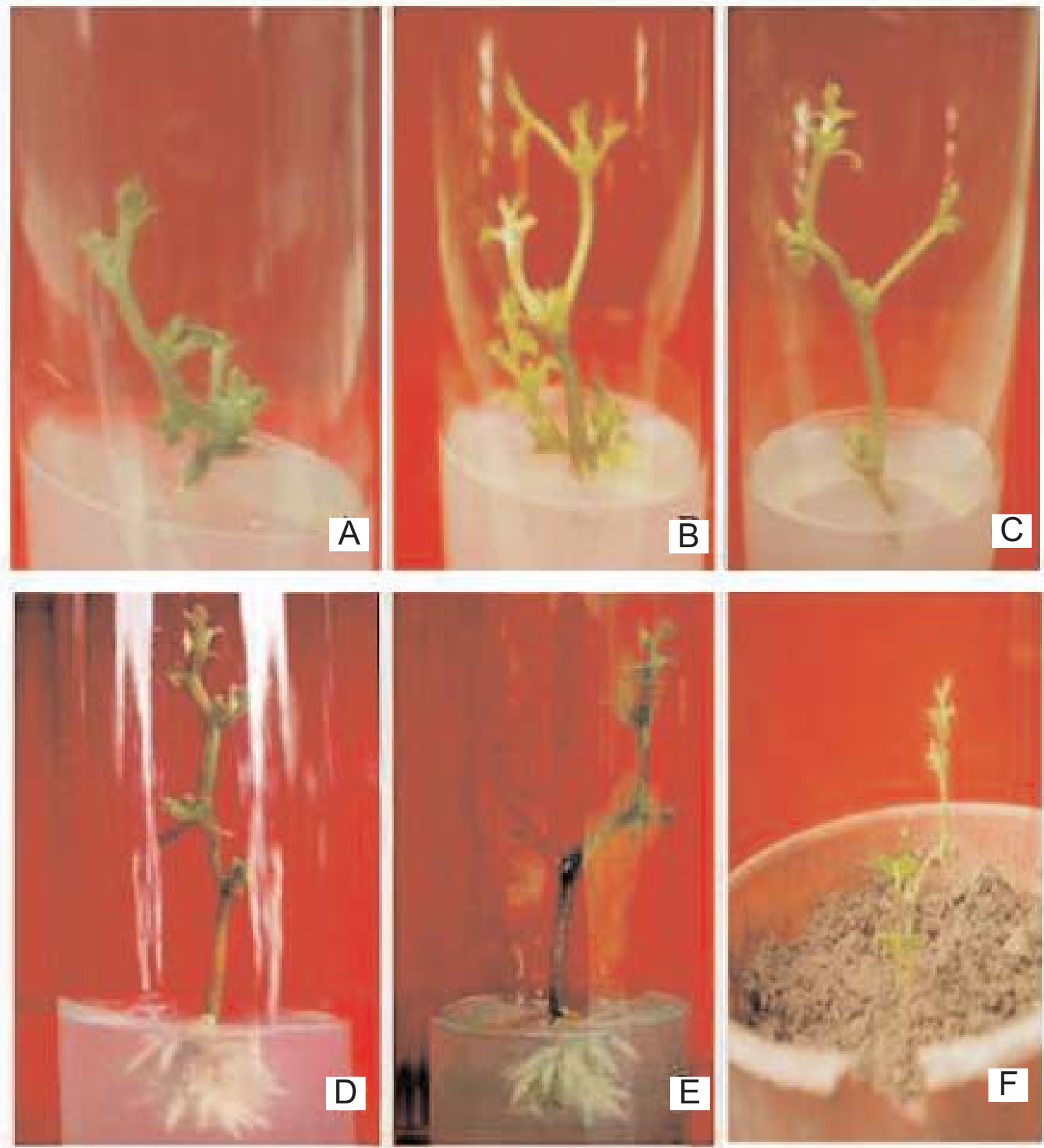

Fig. : In-vitro micropropagation of Trichonsanthes dioica.

A. Multiple shoots regeneration from Shoot tip explant on MS+mg/1BAP $+0.2 \mathrm{mg} / 1$ NAA.

B. Multiple shoots of nodal segment explant on MS $+1 \mathrm{mg} / 1 \mathrm{BAP}+0.2 \mathrm{mg} / 1 \mathrm{NAA}$.

C. Multiple shoots of Shoot tip explant on MS $+1 \mathrm{mg} / 1 \mathrm{BAP}$.

D. Root formation on $1 / 2 \mathrm{MS}+0.5 \mathrm{mg} / 1 \mathrm{BAP}$.

E. Root formation on $1 / 2 \mathrm{MS}+0.4 \mathrm{mg} / 1 \mathrm{BAP}$.

F. Transplantation in earthen pot. 
supplemented with auxin on root induction has been reported in many plants (Ahamed et al., 2005; Huda et al., 2003). Response of different concentrations of NAA, IAA and IBA on half strength MS medium on in vitro adventitious root formation is presented in Table III. The highest percent of root formation $(87.50 \%)$ and number of roots per explant (11) were found in $1 / 2 \mathrm{MS}+0.4 \mathrm{mg} / 1 \mathrm{NAA}$ (Fig. D) which was significantly different from other treatments. Use of auxins singly or in combination for rooting was also reported by different authors (Sahoo and Chand, 1998; Ajithkumar and Seeni, 1998; Rai, 2002; Sivakumar and Krishnamurthy, 2000; Hassan and Roy, 2004; Baksha et al., 2007; Hassan, 2008).

Table III: Effect of different concentrations of NAA, IAA and IBA in $1 / 2$ MS medium on root induction from in vitro grown shoots of pointed gourd

\begin{tabular}{cccc}
\hline $\begin{array}{l}\text { Growth } \\
\text { regulators } \\
(\mathrm{mg} / \mathrm{l})\end{array}$ & $\begin{array}{c}\text { Root } \\
\text { induction (\%) }\end{array}$ & $\begin{array}{c}\text { Days to root } \\
\text { induction }\end{array}$ & $\begin{array}{c}\text { Root number } \\
\text { of explant }\end{array}$ \\
\hline NAA & & & \\
0.1 & - & - & - \\
0.3 & 50.00 & 15 & 7 \\
0.4 & 87.50 & 14 & 11 \\
0.5 & 62.00 & 14 & 10 \\
1.0 & - & - & - \\
\hline IAA & & - & - \\
0.1 & - & 19 & 5 \\
0.3 & 14.29 & 17 & 7 \\
0.5 & 28.57 & - & - \\
1.0 & - & & \\
\hline IBA & & 21 & 6 \\
0.1 & 14.29 & 18 & 8 \\
0.3 & 42.86 & 20 & 7 \\
0.5 & 14.29 & - & - \\
1.0 & - & & \\
\hline
\end{tabular}

The regenerated healthy rooted plantlets were carefully removed from the culture vessels. After thoroughly washing the roots in tap water to remove the traces of nutrients, the rooted plantlets were successfully transferred to plastic pot containing garden soil and compost in ratio of $2: 1$. The pots were immediately covered with polythene bag to prevent desiccation. About $88 \%$ plants were successfully grown. Established plantlets were transferred to the garden soil and it has been also observed that the in vitro raised plantlets were $90 \%$ reestablished.

\section{Conclusion}

The best result was observed in MS medium containing 1.0 $\mathrm{mg} / \mathrm{l} \mathrm{BAP}+0.2 \mathrm{mg} / \mathrm{l} \mathrm{NAA}$ for shoot initiation and multiplication when nodal segment used as explant and in case of root formation, the best result was observed in $1 / 2$ MS medium containing $0.4 \mathrm{mg} / \mathrm{l}$ NAA. These results may be great helpful for the in vitro multiplication of pointed gourd.

\section{References}

Ahamed ABA, Gouthaman T, Rao AS and Rao MV 2005. Micropropagation of Phyla nodiflora (L.) Green; An important medicinal plant. IJB. 3(3): 186-190.

Ajithkumar D and Seeni S 1998. Rapid clonal multiplication through in vitro axillary shoot proliferation of Aegle marmelos (L) Corr., A Medicinal Tree. Plant Cell Rep. 17: $422-426$

Baksha R, Jahan, MAA, Khatun R and Munshi JL 2007. In vitro rapid clonal propagation of Rauvolfia serpentina (Linn.) Benth. Bangladesh J. Sci.Ind. Res. 42(1): $37-$ 44.

Chandrasekar B, Mukherjee B and Mukherjee SK 1988. Blood sugar lowering effect of Trichosanthes dioica Roxb. in experimental rat models. Int. J. Crude Drug Res. 26: 102-106.

Debergh PC and Zimmerman RH 1991. Micropropagation technology and application. Kluer Academic Publishers. Dordrecht. The Netherlands. pp. 181-189.

Debnath RK, Roy SK, Ahmed G and Hossain M 2000. Micropropagation of patal (Trichosanthes dioica Roxb) from nodal segment and shoot tip. Plant Tissue Cult. 10(2): 125-130.

George EF1993. Plant propagation by tissue culture. Part I. the technology. Exegetics Ltd. Edinghon, Wilts, U k. pp. 42.

Hassan AKMS and Roy SK 2004. Micropropagation of Smilax zeylanica L., a perennial climbing medicinal shrub, through axillary shoot proliferation. Bangladesh J. Life Sci. 16(1): 33-39.

Hassan AKMS 2008. In vitro Regeneration of a woody medicinal plant, Pterocarpus santalinus Linn. f., through apical and axillary shoot proliferation. 
Bangladesh J. Life Sci. 20(1): 29-36.

Hosoki Tand Katahira S 1994. Micropropagation of Verbena by node culture. Plant Cell Tissue and Org. Cult. 36(3): 373-375.

Huda S, Islam R, Bari MA and Asaduzzaman M 2003. Shoot differentiation from cotyledon derived callus of chickpea (Cicer arietimum L.). Plant Tissue Cult, 13(1): 5359.

Hutchiunson JM 1981. Tissue Culture: Propagation of fruit trees. In: Proc. COSTED Symp. on Tissue Culture of Economically Important Plants. AN Roy (Ed.), Singapore. pp. 119-120.

Kumar S, Singh BD, Pandey S and Ram D 2007. Inheritance of leaf and stem morphological traits in pointed gourd (Trichosanthes dioica Roxb.). J Crop Improv 21(2).

Murashige T and Skoog F 1962. A revised medium for rapid growth and bio assay with tobacco tissue cultures. Physiol Plant 15: 473-497.

Rai, VR 2002. Rapid clonal propagation of Nothapodytes foetida (Weight) Sleumer - a threatened medicinal tree. In vitro Cell Dev. Biol. Plant. 38: 347-351.

Rashid MM 1993. Vegetable Science (in Bengali) 2nd ed. Rashid Publication. Dhaka. Bangladesh. pp. 494-496.

Satar R and Husain Q 2009. Use of Bitter Gourd (Momordica charantia) peroxidase together with redox mediators to decolorize disperse dyes. Biotechnol. Bioprocess Eng. 14: 213-219.

Sahoo Y and Chand PK 1998. Micropropagation of Vitex nigundo L., a woody aromatic medicinal shrub, through high frequency axillary shoot proliferation. Plant Cell Rep. 18: 301-307.
Sharma G, Pant MC and Sharma G 1988. Preliminary observations on serum biochemical parameters of albino rabbits fed on Trichosanthes dioica (Roxb.). Indian J. Medical Res. 87: 398-400.

Sharma OP 2004. Plant Taxonomy. Tata McGraw Hill Publishing Company Limited, Newdelhi, India., pp: 297-299.

Singh AK, Singh RD and Singh K 1992. Genetic variability, heritability and genetic advance for some traits in pointed gourd (Trichosanthes dioica Roxb.). Haryana J. Hort. Sci. 21(3-4): 236-240.

Singh K 1989. Pointed gourd (Trichosanthes dioica Roxb.). Indian Hort. 33: 35-38.

Sivakumar G and Krishnamurthy KV 2000. Micropropagation of Gloriosa superba L.- an endangered species of Asia and Africa. Current Science. 78(1): 30-32.

Som MG, Maity TK and Hazra P 1993. Pointed Gourd. in Genetic Improvement of Vegetable Crops edited by Kalloo G and Berg BO, Pergamon Press, Oxford, UK.

Uddin S 2000. In vitro propagation of pointed gourd (Trichosanthes dioica Roxb.). M. S. thesis, BSMRAU, Salna, Ga.zipur 1703. p. 2

Vashista PC 1974. Taxonomy of Angiosperms. P.B.M. Press, New Delhi, India.

Zaman A, Islam R, Hossain M, Joarder OI, Ahad A and Barman AC 1992. Clonal propagation through in vitro shoot proliferation of nodal explants of seven mulberry genotypes. Plant Tissue Cult. 2(2): 71-74.

Zimmerman RH and Broome OC 1980. Bluberry micropropagation In: Proc. Cont. Nursing Production of Fruit Plants through Tissue Culture Application and Feasibility, US Dept. Agric. Sci. Edu. Adm, ARRNE11: $44-47$.

Manuscript received on 16 March 2011; revised on 28 July 2011; accepted on 25 September, 2011. 